\title{
Peranan Jajanan Sekolah dan Orang Tua terhadap Karies Gigi Siswa SD di Banda Aceh
}

\author{
Ajeng Tri Sulistyaningrum ${ }^{1}$, Evi Martha ${ }^{2}$
}

\begin{abstract}
1,2Departemen Pendidikan Kesehatan dan Ilmu Perilaku, Public Health Faculty,Indonesia University, Email: ajeng.sulistyaningrum@gmail.com ${ }^{1}$
\end{abstract}

\author{
Kata Kunci : \\ Karies Gigi, Peran Orang Tua, \\ Jenis Makanan, Kesehatan \\ Gigi Dan Mulut, Siswa
}

Keywords:

Dental Caries, The Role of

Parents, Type of Food, Oral

Health, Student

\begin{abstract}
ABSTRAK
Siswa sekolah dasar (SD) merupakan kelompok rentan terhadap kejadian karies gigi.Beberapa penyebab utamanya adalah jenis makanan yang dikonsumsi dan peranan orang tua terhadap perilaku anak dalam menjaga kesehatan gigi dan mulut.Adapun tujuan dilakukannya penelitian ini adalah untuk mengetahui jenis makanan dan peran orang tua terhadap kesehatan gigi dan mulut anak SD.Penelitian ini menggunakan rancang potong lintang yang dilakukan pada bulan Febuari 2016 dengan subjek penelitian pada siswa SD Negeri 48 Deah Glumpang, Kota Banda Aceh. Hasil penelitian menunjukkan lebih dari setengah siswa SD (60\%) memiliki masalah dengan karies gigi sedang. Jenis makanan yang dikonsumsi oleh siswa kebanyakan kurang baik $(68,6 \%)$. Begitu pula halnya dengan peran orang tua terhadap kesehatan gigi dan mulut anaknya kebanyakan kurang baik $(65,7 \%)$. Secara statistik, kejadian karies gigi pada siswa $S D$ memiliki hubungan dengan jenis makanan (nilai $p=0,001$ ) dan peran orang tua (nilai $p=0,005$ ). Oleh karena itu, jenis makanan dan peranan orang tua siswa masih perlu diperhatikan untuk menjaga kesehatan gigi dan mulut siswa.
\end{abstract}

\section{ABSTRACT}

Elementary school students (elementary school) is a group prone to dental caries occurrence. Some of the main causes are the kind of food consumed and the role of parents towards the child's behavior in maintaining oral health. As for the purpose of doing research is to know the types of food consumed and the role of parents against oral health students. This study uses cross-sectional on the latitude of the month of February 2016 with the subject of research on the students of the country 48 Deah Glumpang, Banda Aceh. The results showed more than half of the students (60\%) have problems with dental caries. These types of food consumed by students are mostly amateurish (68.6\%). So it is with the role of parents against her son's mouth and dental health is most unfavorable (65.7\%). Statistically, the incidence of dental caries in students have relationships with different types of food ( $p=0.001$ ) and the role of parents ( $p=0.005)$. Therefore, the type of food and the role of parents of students still need to be advised to maintain oral health students. 


\section{Latar Belakang}

Umumnya, siswa sekolah memiliki risiko terhadap karies gigi. Kebiasaan mengkonsumsi makanan atau minuman yang bersifat karieogenik (manis, lengket, dan berbentuk menarik) adalah makanan yang sering dikonsumsi anak usia Sekolah Dasar (SD) (Prasetya, 2008; Talibo, Mulyadi and Bataha, 2016). Dampak negatif yang ditimbulkan seringnya mengkonsumsi makanan atau minuman tersebut adalah kesehatan gigi dan mulut, khususnya karies gigi karena memiliki kecenderungan melekat pada permukaan gigi. Terjadinya karies gigi dimulai dengan terbentuknya plak pada permukaan gigi yang diakibatkan dari menempelnya sisa makanan pada permukaan gigi. Pada waktu tertentu akan menurunkan $\mathrm{pH}$ mulut menjadi kritis sehingga menyebabkan demineralisasi email sehingga terbentuk menjadi karies gigi(Soesilo, Santoso and Diyatri, 2005).

Dalam studi diet total DKI Jakarta tahun 2014, populasi pada kelompok umur 5-12 tahun atau usia anak SD merupakan paling banyak mengkonsumsi susu kental manis dan susu bubuk dibandingkan dengan kelompok umur lainnya (Puspita et al., 2014). Pada penelitian Kartikasari \& Nuryanto(2014) pada siswa di SDN Kadipaten I dan II Bojonegoro menunjukkan bahwa terdapat hubungan antara karies gigi pada siswa dengan kebiasaan mengkonsumsi makanan yang bersifat karieogenik. Berdasarkan studi pendahuluan yang dilakukan di SDN 48 Deah Glumpang, Banda Aceh diketahui siswa menyukai makanan yang mengandung gula karena mudah untuk didapatkan dan berbentuk menarik.

Peran orang tua dalam menjaga kesehatan gigi dan mulut sangat penting dalam mendasari terbentuknya perilaku yang mendukung kebersihan gigi dan mulut anak. Lingkungan terdekat dan latar belakang keluarga sangat berperan dalam pembentukan sikap dan perilaku di mana anak berada seperti kedekatan dengan keluarga (orang tua) (Christensen, Twetman and Sundby, 2010; Ayu, Sintawati and Andayasari, 2016). Keterlibatan orangtua sangat diperlukan di dalam membimbing, memberikan perhatian, pengertian, mengingatkan dan menyediakan fasilitas kepada anak agar anak kelak dapat memelihara kebersihan giginya. Dalam beberapa penelitian telah dijelaskan mengenai hubungan antara peranan orang tua terhadap kejadian karies gigi (Sumanti, Widarsa and Duarsa, 2013; Ayu, Sintawati and Andayasari, 2016; Husna, 2016). Partisipasi orang tua dalam perawatan kesehatan gigi dan mulut anak berkaitan dengan pengetahuan, sikap, dan motivasi orang tua untuk memeriksakan gigi dan mulut anak.

Tujuan dilakukannya penelitian ini adalah untuk mengetahui makanan yang dikonsumsi dan peranan orang tua terhadap kesehatan gigi dan mulut pada anak usia sekolah dasar (SD) di salah satu sekolah di Kota Banda Aceh. Penelitian ini diharapkan mendapatkan gambaran dan sebagai masukan dalam perencanaan pembangunan kesehatan pada anak sekolah. Dalam penelitian ini dianalisis hubungan konsumsi makanan dan peranan orang tua terhadap kejadian karies gigi pada siswa SDN 48 Deah Glumpang Kecamatan Meuraxa Kota Banda Aceh. 


\section{Metode Penelitian}

Penelitian ini menggunakan rancang potong lintang yang dilakukan pada bulan Febuari 2016 di Deah Glumpang, Kecamatan Meuraxa, Kota Banda Aceh. Pengumpulan data dilakukan dengan pemeriksaan gigi dan wawancara kuesioner. Variabel yang diteliti dalam penelitian ini adalah karies gigi, jenis makanan, dan peranan orang tua.

Subjek dalam penelitian ini adalah siswa SD Negeri 48 Deah Glumpang yang terdiri dari siswa kelas IV (11 orang), kelas V (14 orang), dan kelas VI (10 orang) sejumlah 35 orang. Pemilihan subjek ini diharapkan dapat mempermudah proses pengumpulan data melalui proses wawancara dibandingkan dengan siswa kelas 1, 2, dan 3. Kemudian, gigi permenen telah tumbuh pada kelompok usia siswa di kelas tersebut sehingga dapat mempermudah untuk dilakukannya pemeriksaan kesehatan gigi. Pengambilan sampel dalam penelitian ini dilakukan secara purposive sampling. Peralatan yang digunakan untuk pemeriksaan gigi siswa menggunakan kaca mulut, sonde, excavator, sarung tangan, masker, kapas, alkohol $70 \%$, senter, dan disinfektan. Sedangkan, jenis makanan dan peranan orang tua menggunakan kuesioner. Jenis data dalam penelitian ini adalah kategorik dengan menggunakan skala ukur ordinal dan dianalisis dengan menggunakan uji Chi Square.

Penilaian karies gigi pada siswa menggunakan nilai indeks Decay Missing Filled Teeth (DMF-T). Kemudian, hasil penilaian dibagi menurut 5 tingkat keparahan yaitu: (1) sangat rendah (DMF-T 0,8 - 1,1); (2) rendah (DMF-T 1,2 - 2,6); (3) sedang (DMF-T 2,7 - 4,4); (4) tinggi (DMF-T 4,5 - 6,5); (5) sangat tinggi (DMF-T > 6,5).

Pertanyaan jenis makanan yang dikonsumsi oleh responden terkait dengan makanan yang berisiko terhadap kerusakan pada gigi yang berjumlah 7 pertanyaan mengenai: (1) makanan yang baik untuk kesehatan gigi dan mulut; (2) kesukaan mengkonsumsi makanan sayur - sayuran; (3) kesukaan mengkonsumsi buah-buahan; (4) kesukaan mengkonsumsi eskrim atau makanan dingin; (5) kesukaan mengkonsumsi coklat atau permen; (6) kesukaan mengkonsumsi roti manis; (7) kesukaan mengkonsumsi minuman sirup, air gula dan soda/soft drink. Setelah itu, jawaban responden dikategorikan menjadi 2 berdasarkan skoring yaitu baik (responden menjawab $\geq 11,2$ dari total skor yang diajukan melalui kuesioner) dan kurang baik (jawaban< 11,2 dari total skor yang diajukan melalui kuesioner).

Pertanyaan mengenai peran orang tua terhadap upaya pencegahan terjadinya karies gigi pada anak. Adapun pertanyaan dalam kuesioner berjumlah 5 pertanyaan yaitu: (1) mengingatkan anak untuk menyikat gigi; (2) menjelaskan waktu menyikat gigi; (3) pendampingan menggosok gigi; (4)penjelasan menjaga kesehatan gigi dan mulut; (5)penjelasan menjaga kebersihan gigi dan mulut. Selanjutnya, seluruh jawaban dilakukan skoring dan dibagi menjadi dua kategori baik (menjawab $\geq 8,3$ dari total skor) dan kurang baik (menjawab $<8,3$ dari total skor). 


\section{Hasil Penelitian dan Pembahasan}

\section{Hasil Penelitian}

Tabel 1. Memperlihatkan terdapat 35 responden anak sekolah. Pada awal penelitian dilakukan pemeriksaan gigi siswa dan dilanjutkan dengan wawancara dengan menggunakan kuesioner mengenai jenis makanan dan peran orang tua kepada siswa. Seluruh siswa SD memiliki permasalahan dengan kesehatan gigi mereka. Lebih dari setengah dari siswa SD memiliki masalah dengan karies gigi sedang sebanyak 21 responden $(60 \%)$ dan karies gigi tinggi sebanyak 14 responden (40\%). Setiap siswa memiliki rata-rata 3 sampai 6 karies gigi per responden.

Jenis makanan yang dikonsumsi oleh siswa kebanyakan kurang baik terhadap pemeliharan kesehatan gigi. Lebih dari setengah siswa $(68,6 \%)$ mengkonsumsi makanan kurang baik seperti mengkonsumsi makan manis (permen), kue, coklat, minuman bersoda, dan es krim. Kebanyakan dari mereka mengkonsumsi makanan/minuman yang dapat mengganggu kesehatan gigi, seperti permen, coklat, dan es krim.

Peran orang tua terhadap kesehatan gigi dan mulut anaknya kebanyakan kurang baik $(65,7 \%)$. Peresentase ini menunjukkan kebanyakan orang tua siswa masih kurang berperan terhadap kesehatan gigi dan mulut anak terutama dalam membimbing atau memberikan pengetahuan kepada anak.

Tabel 2. Menunjukkan bahwa makanan baik yang hanya dikonsumsi oleh siswa dengan karies gigi sedang berjumlah 11 orang $(31,4 \%)$ dan tidak terdapat siswa dengan karies gigi tinggi. Sedangkan, jenis makanan kurang baik terhadap karies gigi tinggi (40\%) lebih tinggi dibandingkan dengan karies gigi sedang $(28,5 \%)$. Secara statistik, jenis makanan memiliki hubungan bermakna dengan kejadian karies gigi siswa dengan nilai $p=0,001(p<0,05)$.

Tabel 1. Perilaku dan Kejadian Karies Gigi pada Responden

\begin{tabular}{lcc}
\hline \multicolumn{1}{c}{ Variabel } & Frekuensi $(\mathbf{n = 3 5 )}$ & Presentase \% \\
\hline Karies Gigi & 0 & 0 \\
Sangat Rendah & 0 & 0 \\
Rendah & 21 & 60 \\
Sedang & 14 & 40 \\
Tinggi & 0 & 0 \\
Sangat Tinggi & & \\
Jenis Makanan & 11 & 31,4 \\
Baik & 24 & 68,6 \\
Kurang Baik & & \\
Peran Orang Tua & 12 & 34,3 \\
Baik & 23 & 65,7 \\
Kurang Baik & & \\
\hline
\end{tabular}


Siswa dengan peran orang tua yang baik terhadap pemeliharaan kesehatan gigi dan mulut, terdapat siswa dengan karies gigi sedang $(34,2 \%)$ dan tidak terdapat siswa dengan karies gigi tinggi. Selanjutnya, siswa yang memiliki karies gigi dengan peran orang tua kurang baik lebih banyak pada karies gigi tinggi (40\%) dibandingkan karies gigi sedang $(25,7 \%)$. Hasil uji statistik menunjukkan terdapat hubungan bermakna dengan nilai $\mathrm{p}=$ $0,005(\mathrm{p}<0,05)$ antara kedua variabel.

Tabel 2. Hubungan Karies Gigi dengan Jenis Makanan dan Peran Orang Tua

\begin{tabular}{|c|c|c|c|c|c|c|c|}
\hline \multirow{3}{*}{ Variabel } & \multicolumn{4}{|c|}{ Karies Gigi } & \multirow{2}{*}{\multicolumn{2}{|c|}{ Total }} & \multirow{3}{*}{ Nilai P } \\
\hline & \multicolumn{2}{|c|}{ Sedang } & \multicolumn{2}{|c|}{ Tinggi } & & & \\
\hline & $\begin{array}{c}N \\
(21)\end{array}$ & $\begin{array}{c}\% \\
(59,9)\end{array}$ & $\begin{array}{c}N \\
(14)\end{array}$ & $\begin{array}{c}\% \\
(40,1)\end{array}$ & $\begin{array}{c}N \\
(35)\end{array}$ & $\%$ & \\
\hline \multicolumn{8}{|c|}{ Jenis Makanan } \\
\hline Baik & 11 & 31,4 & 0 & 0 & 10 & 28,5 & \multirow{2}{*}{$0,001^{\mathrm{a}}$} \\
\hline Kurang Baik & 10 & 28,5 & 14 & 40 & 25 & 71,4 & \\
\hline \multicolumn{8}{|l|}{$\begin{array}{l}\text { Peran Orang } \\
\text { Tua }\end{array}$} \\
\hline Baik & 12 & 34,2 & 0 & 0 & 12 & 34,2 & \multirow{2}{*}{$0,005^{\mathrm{a}}$} \\
\hline Kurang Baik & 9 & 25,7 & 14 & 40 & 23 & 65,7 & \\
\hline
\end{tabular}

aUji Chi Square

\section{Pembahasan}

Hubungan jenis makanan dengan karies gigi pada penelitian ini sejalan dengan penelitian Kartikasari \& Nuryanto(Kartikasari and Nuryanto, 2014). Bahan makanan yang sering dikonsumsi dapat mempengaruhi keparahan karies gigi seperti makanan yang mengandung karbohidrat dan gula terolah seperti glukosa (Ramayanti and Purnakarya, 2013). Namun, makanan manis memiliki peranan yang sangat vital terhadap tingkat keparahan karies gigi (Budisuari, Oktarina and Mikrajab, 2010). Siswa SD menyukai makanan manis memiliki kecenderungan untuk mengalami karies gigi lebih tinggi dibandingkan dengan bukan penyuka makanan manis (Sumini, Amikasari and Nurhayati, 2014). Terdapat hal yang memungkinkan siswa mengkonsumsi makanan manis di sekolah karena banyak jenis makanan manis yang dijual di sekitar sekolah.

Minuman berkarbonasi atau minuman ringan juga memiliki hubungan yang signifikan terhadap kejadian karies gigi pada anak sekolah (Prasetyo, 2005; Prasetya, 2008). Selain itu, dalam penelitian Hadnyanawati(2002), kebiasaan mengkonsumsi makan ringan di sekolah terutama pada saat jam istirahat memiliki peranan penting terhadap karies gigi pada siswa. Hal tersebut berpengaruh terhadap terjadinya karies gigi karena terdapat sisa makanan yang menempel di permukaan gigi. Sisa makanan tersebut mengendap dan akan menjadi plak pada gigi. Apabila proses metabolisme oleh bakteri berlangsung lama, hal tersebut akan berakibat pada penurunan $\mathrm{pH}$ dalam jangka waktu lama(Meikawati, Sayono and Nurullita, 2015). Pada saat ini terjadi proses demineralisasi enamel gigi yang kemudian menyebabkan terjadinya karies gigi(Prasetya, 2008). 
Anak usia sekolah merupakan kelompok rentan mengalami karies gigi. Peran orang tua sangat diperlukan untuk memberikan dorongan kepada anak untuk menjaga kesehatan gigi. Faktor pengetahuan, sikap, dan motivasi orang tua terhadap perawatan kesehatan gigi dan mulut pada anakmerupakan faktor yang paling berpengaruh (Sumanti, Widarsa and Duarsa, 2013). Pada penelitian ini, peran orang tua memiliki hubungan secara statistik terhadap pengalaman karies gigi pada siswa. Hasil tersebut sejalan dengan penelitian Eddy \& Mutiara (2015), peran orang tua terutama ibu memiliki pengaruh yang signifikan terhadap perilaku anak dalam menjaga kesehatan gigi khususnya terhadap status karies gigi. Menurut penelitianSari \& Yudhatama(2017), orang tua berperan terhadap pengalaman karies gigi dengan memberikan makanan manis dan susu serta sikap menuntun anak untuk berkumur. Selain itu, gaya hidup ibu seperti mengkonsumsi makanan juga memiliki pengaruh terhadap pengalaman karies gigi karena sangat memungkinkan anak untuk mengikuti kebiasaan orang tua. Hal ini dibuktikan dalam penelitian Wigen \& Wang(2011), pola konsumsi ibu seperti mengkonsumsi gula dan lemak dapat menjadi salah satu faktor risiko terhadap pengalaman karies gigi pada anak.

\section{Kesimpulan}

Makanan menjadi pencetus terbentuknya karies gigi danperan orang tua memiliki pengaruh penting terhadap karies gigi pada responden berdasarkan hasil penelitian ini. Partisipasi pihak sekolah terhadap pengawasan jenis makanan dan minuman yang dikonsumsi oleh anak penting dilakukan. Selain itu, peran orang tua juga sangat diperlukan untuk memberikan asuhan, mendidik, mendorong, dan mengawasi anak dalam menjaga kebersihan gigi agar dapat mencegah terjadinya karies. Oleh sebab itu, upaya promosi kesehatan gigi dan mulut perlu dilakukan terhadap orang tua maupun pihak sekolah.

\section{Ucapan Terima Kasih}

Peneliti mengucapkan terima kasih kepada murid, wali murid, para guru dan kepala sekolah beserta staf SD Negeri 48 Deah Glumpang, Kecamatan Meuraxa, Kota Banda Aceh, serta seluruh pihak yang tidak dapat disebutkan satu per satu yang telah mendukung penelitian ini. 


\section{Daftar Pustaka}

Ayu, M., Sintawati, F. and Andayasari, L. (2016) 'Pengetahuan, Sikap, dan Perilaku Orang Tua tentang Kesehatan Gigi dan Mulut pada Anak Usia Taman Kanak-kanak di Provinsi Daerah Istimewa Yogyakarta dan Provinsi Banten Tahun 2014', Media Litbangkes, 26(2), pp. 119126.

Budisuari, M. A., Oktarina and Mikrajab, M. A. (2010) 'Hubungan Pola Makan dan Kebiasaan Menyikat Gigi dengan Kesehatan Gigi dan Mulut (Karies) di Indonesia', Bulletin Penelitian Sistem Kesehatan, 13(1), pp. 83-91.

Christensen, L. B., Twetman, S. and Sundby, A. (2010) 'Oral Health in Children and Adolescents with Different Socio-cultural and Socio-economic Backgrounds', Acta Odontologica Scandinavica, 68, pp. 34-42. doi: 10.3109/00016350903301712.

Eddy, F. N. E. and Mutiara, H. (2015) 'Peranan Ibu dalam Pemeliharaan Kesehatan Gigi Anak dengan Status Karies Anak Usia Sekolah Dasar', Medical Journal of Lampung University, 4(8), pp. 1-6.

Hadnyanawati, H. (2002) 'Pengaruh Pola Jajan di Sekolah terhadap Karies Gigi pada Siswa Sekolah Dasar di Kabupaten Jember', Jurnal Kedokteran Gigi Universitas Indonesia, pp. 2427.

Husna, A. (2016) 'Peranan Orang tua Dan Perilaku Anak DAlam Menyikat Gigi Dengan Kejadian Karies’, Jurnal Vokasi Kesehatan, 2(1), pp. 17-23.

Kartikasari, H. and Nuryanto (2014) 'Hubungan Kejadian Karies Gigi Dengan Konsumsi Makanan Kariogenik dan Status Gizi Pada Anak Sekolah Dasar (Studi Pada Anak Kelas III dan IV SDN Kadipaten I dan II Bojonegoro', Journal of Nutrition College, 3(3), pp. 414-421. doi: $10.1017 /$ CBO9781107415324.004.

Meikawati, W., Sayono and Nurullita, U. (2015) 'Hubungan Konsumsi Kalsium dalam Makanan dan Minuman dengan Keparahan Karies Gigi pada Murid Kelas IV dan V SDN Mlati Kidul 1 dan 2 Kudus', Jurnal Litbang Universitas Muhammadiyah Semarang, pp. 15-21.

Prasetya, R. C. (2008) 'Perbandingan Jumlah Koloni Bakteri Saliva pada Anak-Anak Karies dan Non Karies Setelah Mengkonsumsi Minuman Berkarbonasi', Indonesian Journal of Dentistry, 15(1), pp. 65-70. doi: 10.14693/jdi.v15i1.86.

Prasetyo, E. A. (2005) 'Keasaman Minuman Ringan Menurunkan Kekerasan Permukaan Gigi', Dental Journal (Majalah Kedokteran Gigi), 38(2), pp. 60-63. doi: 10.20473/j.djmkg.v38.i2.p60-63.

Puspita, D. S. et al. (2014) Survei Konsumsi Makanan Individu dalam Studi Diet Total Provinsi DKI Jakarta 2014. Jakarta: Badan Penelitian dan Pengembangan Kesehatan Kementerian Kesehatan RI. 
Ramayanti, S. and Purnakarya, I. (2013) 'Peran Makanan terhadap Kejadian Karies Gigi', Jurnal Kesehatan Masyarakat, 7(2), pp. 89-93.

Sari, M. and Yudhatama, Y. (2017) 'Pola Asuh Orang Tua terhadap Kejadian ECC (Early Childhood Caries) pada Anak Usia 3-5 Di Kelurahan Purwosari Kota Surakarta', in The 6th University Research Colloquium 2017. Universitas Muhammadiyah Magelang, pp. 303-310.

Soesilo, D., Santoso, R. E. and Diyatri, I. (2005) 'Peranan sorbitol dalam mempertahankan kestabilan $\mathrm{pH}$ saliva pada proses pencegahan karies (The role of sorbitol in maintaining saliva's pH to prevent caries process)', Majalah Kedokteran Gigi (Dental Journal), 38(1), pp. 25-28. doi: 10.20473/j.djmkg.v38.i1.p25-28.

Sumanti, V., Widarsa, T. and Duarsa, P. (2013) 'Laporan hasil penelitian Faktor yang berhubungan dengan partisipasi orang tua dalam perawatan kesehatan gigi anak di Puskesmas Tegallalang I Factors related to parent 's participation in child dental health care in Tegallalang I community health centre P', Public Health and Preventive Medicine Archive, 1(1), pp. 1-7.

Sumini, Amikasari, B. and Nurhayati, D. (2014) 'Hubungan Konsumsi Makanan Manis Dengan Kejadian Karies Gigi Pada Anak Prasekolah Di TK B RA Muslimat PSM Tegalrejodesa Semen Kecamatan Nguntoronadi Kabupaten Magetan', Jurnal Delima Harapan, 3(2), pp. 20-27.

Talibo, R. S., Mulyadi, M. and Bataha, Y. (2016) 'Kebiasaan Menggosok Gigi Dengan Kejadian Karies', e-Journal Keperawatan, 4(1), pp. 1-8.

Wigen, T. I. and Wang, N. J. (2011) 'Maternal Health and Lifestyle, and Caries Experience in Preschool Children. A Longitudinal Study from Pregnancy to Age 5yr', European Journal of Oral Sciences, 119(6), pp. 463-468. doi: 10.1111/j.1600-0722.2011.00862.x. 